University of Nebraska - Lincoln

DigitalCommons@University of Nebraska - Lincoln

Publications from USDA-ARS / UNL Faculty

U.S. Department of Agriculture: Agricultural

Research Service, Lincoln, Nebraska

$10-27-2015$

\title{
Long-Term Corn and Soybean Response to Crop Rotation and Tillage
}

Aaron J. Sindelar

USDA-ARS, aaron.sindelar@ars.usda.gov

Marty R. Schmer

USDA-ARS, marty.schmer@ars.usda.gov

Virginia L. Jin

USDA-ARS, virginia.jin@ars.usda.gov

Brian J. Weinhold

USDA-ARS, Brian.Wienhold@ars.usda.gov

Gary E. Varvel

USDA-ARS, gevarvel@windstream.net

Follow this and additional works at: https://digitalcommons.unl.edu/usdaarsfacpub

Sindelar, Aaron J.; Schmer, Marty R.; Jin, Virginia L.; Weinhold, Brian J.; and Varvel, Gary E., "Long-Term Corn and Soybean Response to Crop Rotation and Tillage" (2015). Publications from USDA-ARS / UNL Faculty. 1559.

https://digitalcommons.unl.edu/usdaarsfacpub/1559

This Article is brought to you for free and open access by the U.S. Department of Agriculture: Agricultural Research Service, Lincoln, Nebraska at DigitalCommons@University of Nebraska - Lincoln. It has been accepted for inclusion in Publications from USDA-ARS / UNL Faculty by an authorized administrator of DigitalCommons@University of Nebraska - Lincoln. 


\title{
Long-Term Corn and Soybean Response to Crop Rotation and Tillage
}

\author{
Aaron J. Sindelar,* Marty R. Schmer, Virginia L. Jin, Brian J. Wienhold, and Gary E. Varvel
}

\begin{abstract}
Long-term experiments are essential to understand how crop rotation and tillage practices affect corn (Zea mays L.) and soybean [Glycine $\max (\mathrm{L}$.) Merr.] production and its resiliency to variable weather conditions. A 28-yr rainfed experiment was conducted in Nebraska to evaluate continuous corn (CC), the corn phase of corn-soybean rotation (CS), continuous soybean (SS), and the soybean phase of corn-soybean rotation (SC), and tillage system (chisel $[\mathrm{CH}]$, tandem disk [DK], moldboard plow [MP], no-till [NT], ridge-tillage [RT], and subsoil tillage [ST]) on grain yield and yield stability. In 19 of $28 \mathrm{yr}$, CS yields were greater than $\mathrm{CC}$, although the corn grain yield advantage in CS decreased as CC yield increased. Rotated soybean (SC) grain yield was greater than SS in 67\% of cropping years, and similar in the remaining $33 \%$. Stability analysis showed that all crop rotation and tillage combinations, except $\mathrm{CH}$ for soybean, resulted in stable grain yields across a range of seasonal weather patterns. Corn grain yields were affected by tillage in $29 \%$ of the years, while NT soybean resulted in consistently high and stable grain yields following an initial 11-yr lag period. We conclude that crop rotation has a greater impact on corn and soybean production than tillage in the western Corn Belt, although nearly all combinations can produce stable yields if well managed.
\end{abstract}

Published in Agron. J. 107:2241-2252 (2015)

doi:10.2134/agronj15.0085

Received 11 Feb. 2015

Accepted 11 July 2015

Copyright (C) 2015 by the American Society of Agronomy

5585 Guilford Road, Madison, WI 53711 USA

All rights reserved
LTHOUGH LONG-TERM AGRONOMIC EXPERIMENTS
require significant insight, financial support, and
time commitment, they offer excellent opportunities to identify crop and soil management factors that maximize and stabilize grain production (Peterson et al., 2012). Such information is greatly needed as we strive to feed a growing world population and adapt to climatic change (Rasmussen et al., 1998). Long-term experiments can provide insight to how crops respond to interactions between agronomic management practices and seasonal variability in weather conditions (Drury and Tan, 1994; Varvel, 1994), notably to abnormal or extreme weather conditions (Verhulst et al., 2011). While short-term research experiments are essential for identifying managementinduced changes in a timely manner, inference of those results on a long-term, ecosystem scale may not be applicable or appropriate (Drinkwater, 2002).

Year-to-year yield stability and resiliency against adverse growing conditions is essential for productive and economically viable cropping systems, particularly in rainfed agroecosystems. Long-term experiments can be used to determine the stability of grain yields under various crop and soil management practices across a range of seasonal weather conditions (Hildebrand, 1984; Raun et al., 1993). However, the number of long-term experiments that have simultaneously analyzed agronomic performance and stability of various crop and soil management practices across a range of weather patterns is limited (e.g., Lyon et al., 1998; Wilhelm and Wortmann, 2004; Grover et al., 2009; Coulter et al., 2011). Stability analyses have been initially used in plant breeding research (e.g., Finlay and Wilkinson, 1963; Becker and Léon, 1988), but can also be used to determine the effectiveness of given crop management practice on yield stability over time. Another gauge of yield stability is the coefficient of variation $(\mathrm{CV})$, which can identify spatial or temporal fluctuation for a specific crop or soil management practice (Smith et al., 2007; Grover et al., 2009).

Tillage system selection is a primary management decision in production agriculture. The use of NT has escalated in recent years to an estimated 36 million hectares (36\%) of U.S. cropland implementing NT in 2009 (Horowitz et al.,

A.J. Sindelar, M.R. Schmer, V.L. Jin, B.J. Wienhold, and G.E. Varvel (retired), USDA-ARS, Agroecosystem Management Research Unit, 251 Food Industry Complex, Univ. of Nebraska-East Campus, Lincoln, NE 68583-0937. *Corresponding author (aaron.sindelar@ ars.usda.gov).

Abbreviations: $\mathrm{CC}$, continuous corn rotation; $\mathrm{CH}$, chisel tillage; $\mathrm{CS}$, corn phase of corn-soybean rotation; DK, disk tillage; DM, dry matter; MP, moldboard plow tillage; NT, no-till; PDSI, Palmer drought severity index; RT, ridge-tillage; SC, soybean phase of corn-soybean rotation; SS, continuous soybean rotation; ST, subsoil tillage.. 
2010). Economically, NT is attractive because individual tillage events are eliminated, thus reducing machinery fuel, energy, and maintenance costs (Lal et al., 2007, Rathke et al., 2007). No-till can also result in the improvement of several soil properties, including greater soil organic matter (Varvel and Wilhelm, 2010), improved soil structure and stability (Abid and Lal, 2008), greater water infiltration (Arshad et al., 1999), and lower erosion susceptibility (Blanco-Canqui et al., 2009). No-till has been suggested as a potential management practice to mitigate climate change through carbon sequestration (Lal, 2004). Additionally, Six et al. (2004) suggested that NT may have a positive effect on net global warming potential with longer-term (>10 yr) adoption. Agronomically, NT yield responses can often be latitude (Griffith and Wollenhaupt, 1994) and precipitation dependent (Norwood and Currie, 1996; Klocke et al., 2009). In northern temperate environments where cool soil temperatures can adversely affect crop emergence and early-season growth, yields with NT can often be reduced. For example, Pedersen and Lauer (2003) reported that NT reduced corn yield by $5 \%$ across multiple crop rotations in Wisconsin. In Minnesota, NT reduced corn and soybean yields more than intensive tillage systems (Vetsch et al., 2007). In contrast, Norwood (1999) reported greater corn, soybean, and grain sorghum [Sorghum bicolor (L.) Merr.] grain yields with NT by 31,15 , and $10 \%$, respectively, over a 4 -yr period in Kansas. Dickey et al. (1994) reported that soybean and grain sorghum yields with NT were either equal to or greater than more intensive tillage systems over a 5-yr period in Nebraska. A 3-yr multi-location study in Nebraska by Sims et al. (1998) further demonstrated the influence of environment on the response of corn grain yield to tillage system. In eastern Nebraska, NT adoption often resulted in reduced corn grain yield, while corn grain yield with NT was similar to if not greater than conventional tillage in south-central Nebraska.

Crop rotation has also been shown to have an impact on cropping system performance (e.g., Porter et al., 1997; Wilhelm and Wortmann, 2004; Grover et al., 2009). In corn- and soybean-based rotations, studies have demonstrated that grain yields are often greater when grown in rotation than continuously. In a multi-location study in Minnesota and Wisconsin by Porter et al. (1997), corn in rotation with soybean yielded 10 to $16 \%$ more grain than when grown continuously. In the same study, soybean yielded 5 to $16 \%$ more grain when grown in rotation with corn than when grown continuously. Pedersen and Lauer (2003) reported that corn and soybean in a CS rotation resulted in 18 and $13 \%$ greater grain yields, respectively, than when grown continuously in Wisconsin. At a rainfed site in eastern Nebraska, corn and soybean grain yield was 38 and $13 \%$ greater, respectively, when grown in rotation than when grown continuously (Peterson and Varvel, 1989a, 1989b).

While crops grown in rotation often exhibit greater yields than those grown continuously, the yield advantage associated with the rotation effect can be dependent on seasonal weather conditions. In addition, crop rotations do not always reduce yield variability. In a multi-location study in Minnesota and Wisconsin (Porter et al., 1997), the yield advantage associated with rotated corn and soybean decreased by 4 and $6 \%$ for each $\mathrm{Mg} \mathrm{ha}^{-1}$ increase in continuous corn and soybean yield, respectively. In another study by Porter et al. (1998), the CV for grain yield associated with CS was greater than that with $\mathrm{CC}$ at two of three locations. For soybean, the CV for SS was less than that for SC at one of three locations. However, these studies were performed in environments that are commonly affected by cool early season temperatures. Therefore, it is not known if similar yield responses occur in other environments. For example, Grover et al. (2009) found that neither grain yield nor its corresponding CV differed between CC and CS over a 16 -yr period in Pennsylvania. Further long-term research is needed to quantify the interaction between the rotation effect and environment.

Identifying tillage systems and crop rotations that result in productive and stable grain yields is imperative toward establishing and maintaining sustainable and profitable cropping systems. Evaluation of these crop and soil management practices in a long-term study provides the opportunity to assess these practices over an array of weather conditions, particularly those considered to be abnormal or extreme. These long-term responses not only determine yield performance, but also identify the stability and resiliency of differing crop and soil management practices. The objective of this study was to evaluate long-term yield and yield stability of corn and soybean grain and biomass as affected by tillage system and crop rotation at a rainfed site in the western Corn Belt.

\section{MATERIALS AND METHODS}

This ongoing study was established in 1986 at a site $10 \mathrm{~km}$ east of Lincoln, $\mathrm{NE}\left(40^{\circ} 5^{\prime} \mathrm{N}, 96^{\circ} 3^{\prime} \mathrm{W}\right)$ on Aksarben (fine, smectitic, mesic Typic Argiudoll) and Wymore (fine, smectitic, mesic Aquertic Argiudoll) silty clay loam soils (Wilhelm and Wortmann, 2004; Varvel and Wilhelm, 2010). The site is rainfed and averages $72.8 \mathrm{~cm}$ of annual precipitation and an air temperature of $11.0^{\circ} \mathrm{C}$. The site is representative of the region, as corn and soybean grain yield correlations between annual study means and USDA-National Agricultural Statistics Service (NASS) county means were significant $(P$ $\leq 0.001$ ) (Fig. 1A and 1B). Before the study, corn was grown continuously for $6 \mathrm{yr}$. The experimental design is a split plot arrangement in a randomized complete block design with six replications. Main plots are tillage system and split plots are crop rotation. Both corn and soybean phases of the rotation are present each year. Split plots are $4.6 \mathrm{~m}$ wide (six $0.76-\mathrm{m}$ rows) by $22.9 \mathrm{~m}$ long.

Chisel tillage, MP, and ST operations were performed annually following grain harvest. From 1986 to 1999, crop residues in plots planted to corn were chopped before tillage. Approximate tillage depth was $25 \mathrm{~cm}$ for $\mathrm{CH}$ and $\mathrm{MP}$ and $36 \mathrm{~cm}$ for ST. The $\mathrm{CH}$ unit included shanks equipped with straight points with $25-\mathrm{cm}$ spacing. The MP treatment resulted in full inversion of the tillage slice. The subsoil unit (Blu-jet Subtiller, Thurston Manufacturing Co., Thurston, NE) was equipped with standard shanks and fall-till points with $76-\mathrm{cm}$ spacing. Corn residues were chopped in the spring in the DK, NT, and RT treatments. All tilled treatments except RT (CH, DK, MP, ST) were again disked before planting to a depth $<10 \mathrm{~cm}$. In addition to this tillage event, DK was tilled again, resulting in two tillage events in the spring. No pre-plant tillage operations were applied to NT or RT. 
Corn and soybean were planted at dates and seeding populations according to local recommendations. Both crops were planted in 76-cm rows with a planter equipped with doubledisk openers. Scalloped trash disks were adjusted to remove 3 to $5 \mathrm{~cm}$ of soil from the top of the ridge in the RT treatment, and $\leq 2 \mathrm{~cm}$ of soil and the old corn crown in the NT treatment. Corn was typically planted within the first 2 wk of May. In 1995, corn planting did not occur until late May because of wet soils delaying field entry. Seeding population ranged from 40,000 to 50,400 seeds $\mathrm{ha}^{-1}$ between 1986 and 1995, and has been 57,500 seeds $\mathrm{ha}^{-1}$ since 1996 . Corn hybrids were selected to match growing degree unit availability of the region, and have utilized transgenic resistance to glyphosate [ $N$-(phosphonomethyl)glycine], European corn borer (Ostrinia nubilalis), and corn rootworm (Diabrotica spp.) as technologies became available. Soybean seeding rates ranged from 247,000 to 424,800 seeds ha ${ }^{-1}$ over the duration of the study. Selected soybean cultivars have been an early III maturity group and have had transgenic resistance to glyphosate since 1998.

In-season management included $\mathrm{N}$ fertilizer application for corn, herbicide application, and field cultivation (in tilled treatments). Fertilizer $\mathrm{N}$ was broadcast applied to corn at approximately the $\mathrm{V} 3$ growth stage (Abendroth et al., 2011) as ammonium nitrate at $112 \mathrm{~kg} \mathrm{~N} \mathrm{ha}^{-1}$ from 1986 to 2003 , and at $168 \mathrm{~kg} \mathrm{~N} \mathrm{ha}^{-1}$ from 2004 to 2006. In 2007, fertilizer $\mathrm{N}$ source and placement was changed to urea via injection knives to a depth of 10 to $15 \mathrm{~cm}$, while the rate remained consistent at $168 \mathrm{~kg} \mathrm{~N} \mathrm{ha}^{-1}$. All other nutrients were considered to be acceptable for corn and soybean production (Ferguson et al., 2000a,2000b). Insecticides were used before hybrid use with corn rootworm resistance. Specific insecticides varied year-toyear and were applied at planting according to label instructions. Over the duration of the study, a combination of pre- and post-emergent herbicides, cultivation, and hand weeding were used for weed control. Cultivation of corn and soybean in all tillage treatments except NT occurred between the V5 and V8 (Abendroth et al., 2011) and V5 (Ritchie et al., 1997) growth stages, respectively. The RT treatment was ridged at or within 2 wk of this cultivation. A Buffalo row-crop cultivator (Fleischer Manufacturing Co., Columbus, NE) was used for cultivation and ridging.

Corn and soybean dry matter (DM) and grain harvest occurred once crops reached physiological maturity. Cellulosic DM (all aboveground DM minus grain) yield determination began in 1997 from an area $0.76 \mathrm{~m}$ wide by $3.0 \mathrm{~m}$ long. For corn, ears were removed from the plant, dried at $60^{\circ} \mathrm{C}$ to a constant mass, and shelled before weighing both the grain and cobs. The remaining plant material was cut at ground level, chopped, and weighed. A subsample was dried at $60^{\circ} \mathrm{C}$ until constant mass was reached for DM calculation. Before 1998, grain yields were determined by hand harvesting an area of 9.3 or $4.6 \mathrm{~m}^{2}$ for corn and soybean, respectively. For corn, grain was shelled from the ear, weighed, and sampled for moisture determination. For soybean, whole plants were air dried and threshed to obtain grain. Grain was then weighed and sampled for moisture determination. Since 1998, corn and soybean yields have been determined through combine harvest of three non-border, non-DM yield determination rows. All corn and soybean grain yields were adjusted to 155 and $130 \mathrm{~g} \mathrm{~kg}^{-1}$
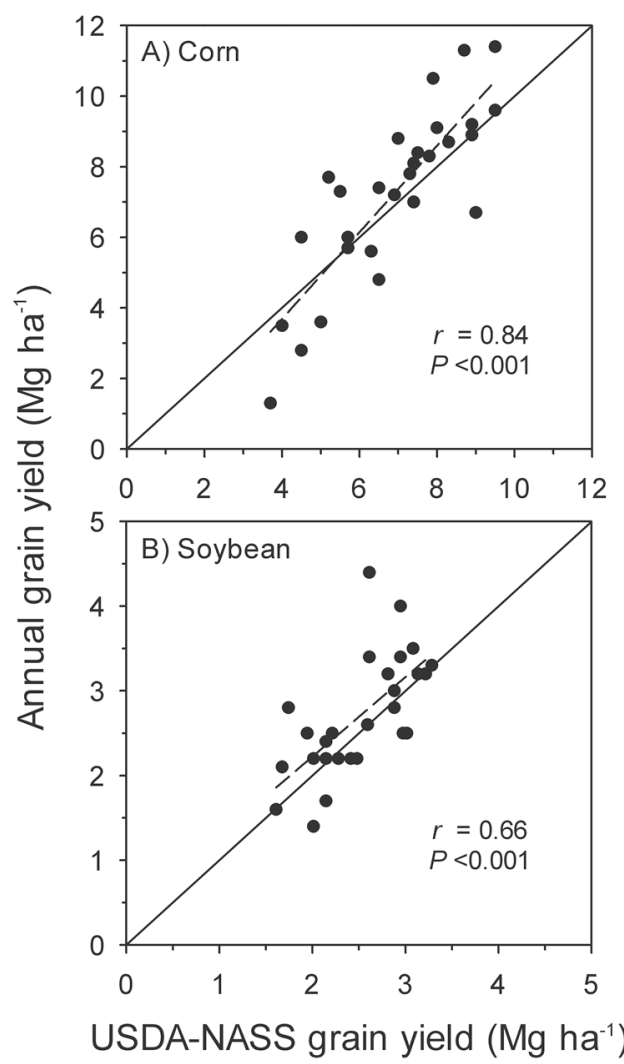

Fig. I. Correlations for (A) corn and (B) soybean grain yield between USDA-National Agricultural Service (NASS) means for Lancaster County, NE (USDA-NASS, 20I4), and annual study means. The solid diagonal line represents the I:I line.

moisture, respectively. Cellulosic and grain yields, on a DM basis, were summed together to quantify total DM production.

Since precipitation event distribution and intensity can vary, the Palmer drought severity index (PDSI) for the growing season was obtained to identify periods of abiotic stress (Alley, 1984; NOAA-NCDC, 2014). Values $\leq-0.50$ identify various degrees of drought, while those that range from -0.49 to 0.49 are categorized as near normal (Alley, 1984). Data were analyzed using the GLIMMIX procedure of SAS (SAS Institute, 2014 ) with differences significant at $P \leq 0.05$. Since measurements were taken on the same experimental unit (plot) over time, a repeated measures analysis was conducted on DM and grain yield response variables. Tillage system, crop rotation, time, and the corresponding interaction were considered to be fixed effects, while block were random. In this scenario, year was converted to a time-point context (1-28 yr) and considered to be the repeated measure. Interactions associated with block were omitted because of potential interference with covariance structures (Loughin, 2006; Baldock et al., 2014). The selected covariance structure for each response variable produced the smallest Akaike Information Criterion (Littell et al., 2006; Loughin, 2006). Significant treatment responses within individual time points were identified using the SLICE option in the LSMEANS statement $(P \leq 0.05)$. Mean comparisons were made using the PDIFF option $(P \leq 0.05)$. To assess spatial stability, the CV was calculated for each tillage system $\times$ crop rotation treatment within each year and analyzed using the GLIMMIX procedure in SAS. In this analysis, tillage system, crop rotation, and the corresponding interaction were 
considered to be fixed effects, while year and corresponding interactions were random.

Regression stability analyses for corn and soybean grain yields were performed to quantify stability of the treatments across a range of seasonal weather conditions (Grover et al., 2009; Coulter et al., 2011). These were calculated based on significant tillage system and crop rotation main effects for both corn and soybean (Table 1) according to the procedure by Finlay and Wilkinson (1963). The long-term yield stability of a given treatment to seasonal weather variation was evaluated by regressing least-square annual treatments means on the least-square annual means (averaged across all treatments) using the REG procedure of SAS (SAS Institute, 2014). To determine stability, the $\hat{\beta}_{1}$ (slope) estimate was tested for its equivalence to one with contrasts using the TEST statement in the REG procedure of SAS. When $\hat{\beta}_{1}=1$, the given treatment is regarded as stable, meaning its response to different weather conditions is similar to the overall environmental response (averaged across all crop management practices). When $\hat{\beta}_{1}$ is $<$ or $>$ than 1 , it is considered to have a reduced or greater stability in response to weather conditions, respectively (Coulter et al., 2011), particularly as yield potential of the environment increases. Parameter estimates of treatments $\left(\hat{\beta}_{0}\right.$ and $\left.\hat{\beta}_{1}\right)$ were also compared to determine stability differences using the TEST statement of the REG procedure of SAS. When $\hat{\beta}_{0}$ differed between treatments, it signified a general yield difference in years where abiotic factors, namely weather conditions, greatly limited yield potential.

\section{RESULTS}

\section{Growing Season}

Over the duration of the study, in-season precipitation (1 May-30 September) was $44.8 \mathrm{~cm}$, representing $61 \%$ of the annual precipitation $(72.8 \mathrm{~cm}$ ) (Fig. $2 \mathrm{~A}$ and $2 \mathrm{~B})$. Year-to-year variability of in-season precipitation ranged from 22.9 to $48.6 \mathrm{~cm}$ (Fig. 2A), and annual precipitation ranged from 87.2 to $108.7 \mathrm{~cm}$ (Fig. 2B). The majority of years (22 of 28 ) were within $20 \mathrm{~cm}$ of the study mean (Fig. 2A). Only $10 \mathrm{yr}$ received precipitation amounts that were greater than the study mean. However, in four of these years, in-season precipitation was 43 to $95 \%$ greater than the study mean. In-season and annual air temperature averaged 21.3 and $11.0^{\circ} \mathrm{C}$ over the timespan of the study, respectively (Fig. 2A and 2B). Similar to precipitation, average daily air temperature during the growing season varied among years, and ranged from 19.3 to $23.2^{\circ} \mathrm{C}$ (Fig. 2A).
While the growing season PDSI site mean over the duration of the study was considered to be average, only three individual years were classified as such (Fig. 3). Thirteen years were classified as at least incipient wet spells $(\geq 0.50)$, while $11 \mathrm{yr}$ were classified as at least incipient drought $(\leq-0.50)$. The PDSI for drought conditions $(\leq-1.0)$ were generally years when below-average precipitation amounts were accompanied by above-average seasonal temperatures (Fig. 2A and 3). However, anomalies did exist, specifically in 1989. In this year, seasonal precipitation and temperature were $10.0 \mathrm{~cm}(22 \%)$ greater and $0.4^{\circ} \mathrm{C}$ less than the study average, respectively. In comparison, the PDSI was $\leq-4.0$, which is categorized as extreme drought (Alley, 1984). One possible explanation for this discrepancy is that multiple rainfall events in 1989 may have been low frequency and high intensity, which could potentially reduce their effectiveness (i.e., significant runoff losses). Conversely, the PDSI identified 4 yr classified as near-normal and an additional 14 classified as incipient wet spells to extremely wet $(0.5-4.0)$ (Fig. 2). Therefore, a wide range of growing conditions existed over the duration of the study, with some that could be considered severe, as classified by the PDSI.

\section{Corn Dry Matter and Grain Yield}

The separate interactions of tillage system and crop rotation with time were significant for corn DM biomass yield (Table 1). Over 16 growing seasons where corn DM yield was measured (1997-2013), differences among tillage systems existed in 6 yr (Table 2). Corn DM yield with MP and NT was greatest or equal to the greatest in five and four of six responsive years, respectively. Conversely, corn DM yield with $\mathrm{CH}$ was least or equal to the least in all six responsive years. Corn DM yield ranged from 3.3 to $18.5 \mathrm{Mg} \mathrm{DM} \mathrm{ha}^{-1}$ within crop rotation by year treatments. When crop rotations were compared, corn DM yields differed between CC and CS in 12 of $16 \mathrm{yr}$. In these years, corn DM yield was greater with CS than CC by 6 to $69 \%$ $(P<0.001$ to 0.0485$)$. The CV for corn DM yield was affected by the main effects of tillage system and crop rotation (Table 1). When the $\mathrm{CV}$ for corn DM yield was compared across tillage treatments, the CV for ST (19.9\%) was greater than all other tillage systems (14.4 to $16.9 \%$ ), while no differences existed among the remaining tillage systems (Table 2). When crop rotations were compared, the $\mathrm{CV}$ for corn DM yield was greater with CC (17.5\%) than CS (15.6\%).

Significant tillage system $\times$ time and crop rotation $\times$ time interactions were present for corn grain yield (Table 1), and it differed among tillage systems in 8 of $28 \mathrm{yr}$ (Table 3 ). Within

Table I. Tests of effects for total dry matter (DM) and grain yields and its respective coefficient of variation (CV) for corn and soybean.

\begin{tabular}{|c|c|c|c|c|c|c|c|c|}
\hline \multirow[b]{2}{*}{ Source of variation } & \multicolumn{4}{|c|}{ Corn } & \multicolumn{4}{|c|}{ Soybean } \\
\hline & Total DM yield & $\begin{array}{l}\text { Total DM } \\
\text { yield CV }\end{array}$ & Grain yield & $\begin{array}{l}\text { Grain yield } \\
\text { CV }\end{array}$ & $\begin{array}{c}\text { Total DM } \\
\text { yield }\end{array}$ & $\begin{array}{l}\text { Total DM } \\
\text { yield CV }\end{array}$ & Grain yield & $\begin{array}{c}\text { Grain yield } \\
\text { CV }\end{array}$ \\
\hline Time $(Y)$ & $<0.001$ & & $<0.001$ & & $<0.001$ & & $<0.001$ & \\
\hline Tillage system $(\mathrm{T})$ & $<0.001$ & 0.0070 & $<0.001$ & 0.2492 & $<0.001$ & 0.0191 & 0.0604 & 0.6818 \\
\hline Crop rotation (R) & $<0.001$ & 0.0259 & $<0.001$ & $<0.001$ & $<0.001$ & 0.3130 & $<0.001$ & 0.0702 \\
\hline$Y \times T$ & 0.0114 & & $<0.001$ & & 0.1878 & & $<0.001$ & \\
\hline$Y \times R$ & $<0.001$ & & $<0.001$ & & $<0.001$ & & $<0.001$ & \\
\hline$T \times R$ & 0.3764 & 0.9000 & 0.9536 & 0.9118 & 0.1594 & 0.8350 & 0.8225 & 0.2731 \\
\hline$Y \times T \times R$ & 0.9831 & & 0.8913 & & 0.9863 & & 0.8779 & \\
\hline
\end{tabular}


years and significant interactions, no unanimous rankings were apparent. All tillage systems exhibited instances when corn grain yield was the greatest or equal to the greatest in multiple years, but also least or equal to the least in multiple years, with the exception of ST. Corn grain yield with ST was equal to the greatest in 1987 and equal to the least in six of eight significant years. Corn grain yield with MP was greatest or equal to the greatest 6 of $8 \mathrm{yr}$, but was also the least in the other $2 \mathrm{yr}$. Corn grain yield differed between crop rotations in 19 of $28 \mathrm{yr}$ (Table 3). Grain yield was greater with $\mathrm{CS}$ than $\mathrm{CC}$ in all responsive years by 7 to $105 \%(P<0.001-0.0168)$. The $\mathrm{CV}$ for corn grain yield differed between crop rotations (Table 1), with a greater CV for CC (17.7\%) than CS (13.6\%). Corn grain yield CV was similar by tillage system averaging $15.5 \%$ (Table 3 ).

The linear slope $\left(\hat{\beta}_{1}\right)$ of corn grain yield regressed on the environmental mean was similar to one for all tillage systems and crop rotations $(P=0.0901$ to 0.9275$)$, indicating responses of corn grain yield to different seasonal weather conditions were stable for all tillage systems and crop rotations (Table 4). Differences did exist when parameter estimates were compared between tillage systems and crop rotations. Only DK and NT differed, as both $\hat{\beta}_{0}$ and $\hat{\beta}_{1}$ were different $(P=0.0353$ and 0.0230 , respectively). In this case, $\hat{\beta}_{0}$ was less for DK than NT, while the inverse was true for $\hat{\beta}_{1}$. No other differences among tillage systems occurred for any other parameter estimate. For crop rotation, both parameter estimates differed as $\hat{\beta}_{0}$ for CS was greater than that for $\mathrm{CC}$, while the inverse relationship was true for $\hat{\beta}_{1}$.

\section{Soybean Dry Matter and Grain Yield}

Soybean DM yield was affected by tillage system $(P<0.001)$ and the crop rotation $\times$ time interaction $(P<0.001)$ (Table 1). The response of soybean DM yield (1997-2013) to tillage system was consistent across years and crop rotations (Table 5). Soybean DM yield with NT was 5 to $37 \%$ greater ( 0.7 and 4.4 Mg DM ha ${ }^{-1}$, respectively) than all other tillage systems. In comparison, soybean DM yield with $\mathrm{CH}$ was the least when compared to all other tillage systems excluding RT. Soybean DM yield with DK, MP, ST, and RT were determined to be similar. Soybean DM yield was 8 to $42 \%$ greater with SC than with SS in 13 of 16 responsive years. In the remaining years,
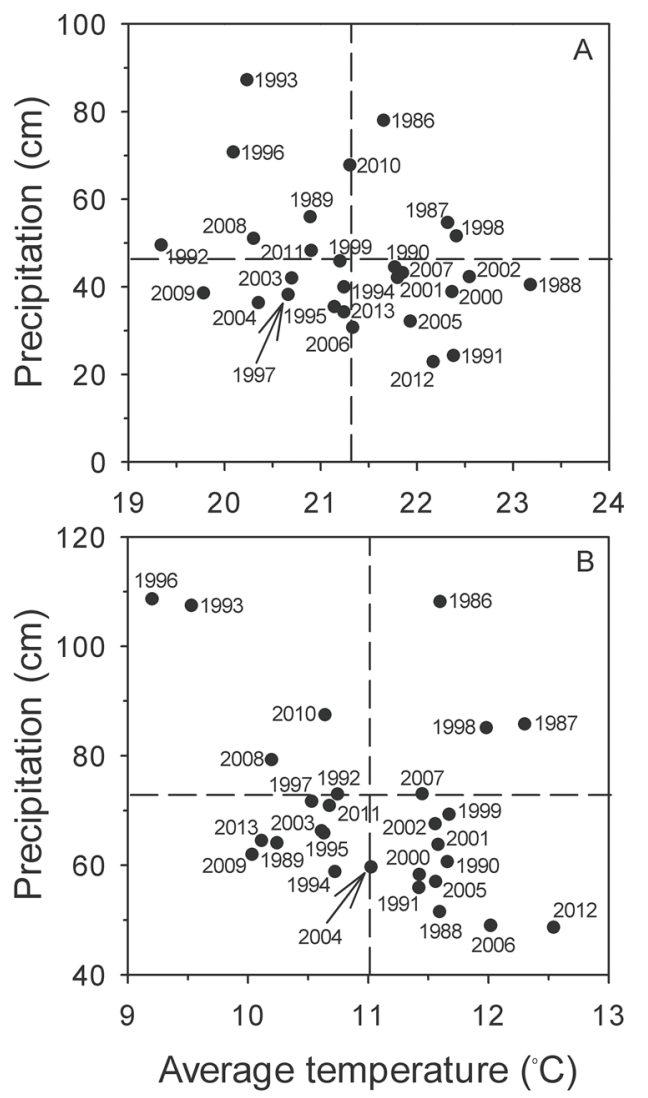

Fig. 2. (A) In-season (I May-30 September) and (B) annual temperature and precipitation distribution of individual years over the duration of the study. Dashed lines indicate the study means for precipitation and temperature.

soybean DM yield did not differ between crop rotations and averaged 4.4, 6.7, 7.1 $\mathrm{Mg} \mathrm{DM} \mathrm{ha}^{-1}$, which was 75, 113, and $120 \%$ of the study mean, respectively. The CV for soybean DM yield was affected by the main effect of tillage system (Table 1) and was observed to be the greatest or equal to the greatest with DK, MP, RT, and ST, and least or equal to the least with $\mathrm{CH}, \mathrm{NT}$, RT, and ST (Table 5).

The crop rotation $\times$ time and tillage system $\times$ time interactions were significant for soybean grain yield (Table 1). Soybean grain yield differed among tillage systems in 7 of

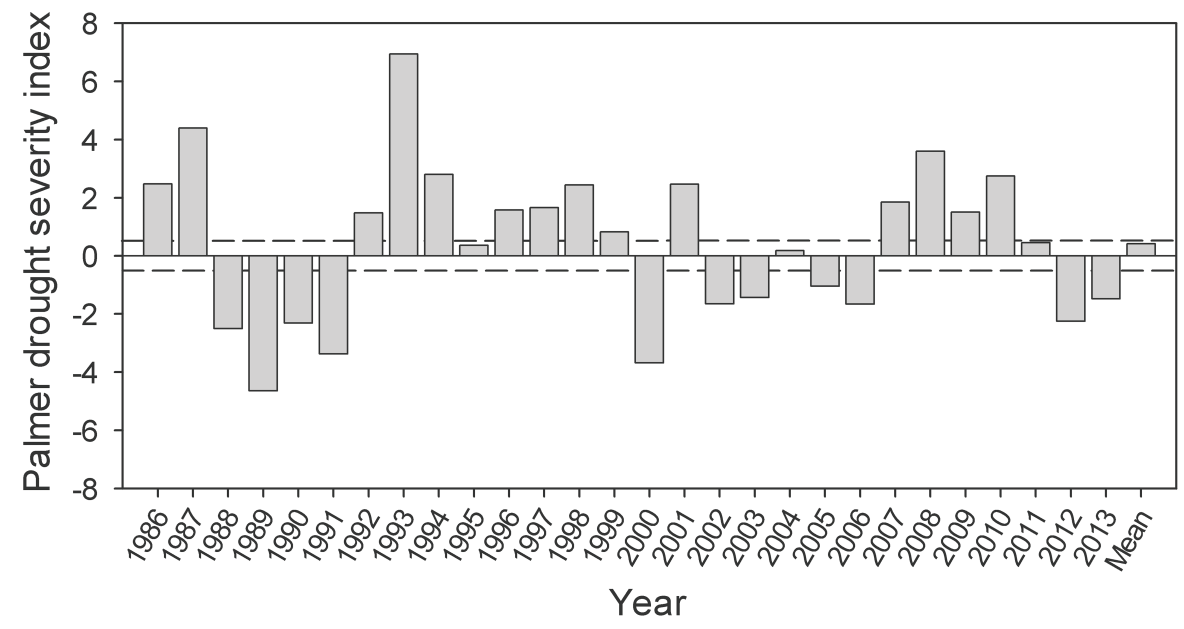

Fig. 3. Palmer drought severity index (PDSI) during the growing season for southeastern Nebraska (I May-30 September). Area within dashed lines identifies the PDSI range classified as near normal (Alley, 1984). 
Table 2. Corn dry matter (DM) production and the coefficient of variation (CV) as affected by tillage system (CH, chisel; DK, disk; MP, moldboard plow; NT, no-till; RT, ridge-tillage, ST, subsoil tillage) and crop rotation (CC, continuous corn; CS, corn phase of corn-soybean rotation) from 1997 to 2013 .

\begin{tabular}{|c|c|c|c|c|c|c|c|c|c|c|c|}
\hline \multirow[b]{2}{*}{ Year } & \multicolumn{6}{|c|}{ Tillage system } & \multirow{3}{*}{$\begin{array}{l}F \text { test } \\
P>F\end{array}$} & \multicolumn{3}{|c|}{ Crop rotation } & \multirow[b]{2}{*}{ Annual mean } \\
\hline & $\mathrm{CH}$ & DK & MP & NT & RT & ST & & $\mathrm{CC}$ & CS & $F$ test & \\
\hline & \multicolumn{6}{|c|}{ - Mg DM ha } & & \multicolumn{2}{|c|}{ - Mg DM ha- } & $P>F$ & $M g$ DM ha-1 \\
\hline 1997 & 11.6 & 11.3 & 13.7 & 11.6 & 11.6 & 10.9 & 0.0532 & $10.8 \mathrm{~b} \dagger$ & $12.8 \mathrm{a}$ & $<0.001$ & 11.8 \\
\hline 1998 & $16.1 \mathrm{~B} \ddagger$ & I6.4B & $18.5 \mathrm{~A}$ & I5.6B & I5.4B & I6.0B & 0.0156 & $15.3 \mathrm{~b}$ & $17.4 \mathrm{a}$ & $<0.001$ & 16.3 \\
\hline 1999 & 14.0 & 15.8 & 15.5 & 15.8 & 13.7 & 15.0 & 0.1051 & $13.2 b$ & $16.7 \mathrm{a}$ & $<0.001$ & 15.0 \\
\hline 2000 & $12.1 \mathrm{~B}$ & $12.8 \mathrm{AB}$ & $9.7 \mathrm{C}$ & $14.4 \mathrm{~A}$ & $1 \mathrm{I} .2 \mathrm{BC}$ & $12.6 \mathrm{AB}$ & $<0.001$ & 12.5 & 11.7 & 0.1293 & 12.1 \\
\hline 2001 & 16.4 & 16.0 & 15.6 & 16.8 & 15.1 & 16.1 & 0.5351 & $15.0 \mathrm{~b}$ & 17.0a & $<0.001$ & 16.0 \\
\hline 2002 & 4.0 & 4.4 & 4.9 & 5.8 & 4.0 & 3.7 & 0.2230 & $3.3 b$ & $5.6 a$ & $<0.001$ & 4.5 \\
\hline 2003 & 14.3 & 13.8 & 14.6 & 14.4 & 14.0 & 14.0 & 0.6973 & $13.6 \mathrm{~b}$ & $14.7 \mathrm{a}$ & 0.0485 & 14.2 \\
\hline 2004 & 18.0 & 18.4 & 18.5 & 17.9 & 18.4 & 17.1 & 0.7137 & 17.5 & 18.5 & 0.0743 & 18.0 \\
\hline 2005 & $9.1 \mathrm{C}$ & $11.2 \mathrm{AB}$ & $11.8 \mathrm{~A}$ & $11.7 A B$ & $9.9 B C$ & $10.0 \mathrm{ABC}$ & 0.0193 & $9.3 b$ & $12.0 \mathrm{a}$ & $<0.001$ & 10.6 \\
\hline \multicolumn{12}{|l|}{$2006 \S$} \\
\hline 2007 & $11.8 \mathrm{bC}$ & $13.8 \mathrm{~A}$ & I3.0AB & $13.3 \mathrm{AB}$ & $11.0 \mathrm{C}$ & $12.5 \mathrm{ABC}$ & 0.0436 & $12.0 \mathrm{~b}$ & $13.1 \mathrm{a}$ & 0.0434 & 12.6 \\
\hline 2008 & $16.6 \mathrm{~B}$ & I7.0AB & I8.7A & I5.2B & $16.2 B$ & $16.1 \mathrm{~B}$ & 0.0108 & $15.2 \mathrm{~b}$ & 18.0a & $<0.001$ & 16.6 \\
\hline 2009 & I6.0B & $16.3 \mathrm{~B}$ & $18.2 \mathrm{~A}$ & I7.5AB & 16.0B & $18.0 \mathrm{~A}$ & 0.0446 & $16.4 \mathrm{~b}$ & $17.6 \mathrm{a}$ & 0.0253 & 17.0 \\
\hline 2010 & 13.0 & 14.6 & 12.6 & 13.9 & 13.5 & 12.9 & 0.2809 & $11.3 b$ & $15.5 \mathrm{a}$ & $<0.001$ & 13.4 \\
\hline 2011 & 16.0 & 17.2 & 18.4 & 16.9 & 16.1 & 17.4 & 0.1246 & 16.7 & 17.4 & 0.2269 & 17.0 \\
\hline 2012 & 7.4 & 8.0 & 9.2 & 7.8 & 7.1 & 7.9 & 0.3530 & $7.4 \mathrm{~b}$ & $8.5 a$ & 0.0433 & 7.9 \\
\hline 2013 & 13.3 & 14.1 & 15.0 & 14.0 & 14.1 & 14.5 & 0.6208 & 14.6 & 13.7 & 0.1100 & 14.2 \\
\hline Mean & 13.1 & 13.8 & 14.2 & 13.9 & 13.0 & 13.4 & & 12.8 & 14.4 & & 13.6 \\
\hline CV (\%) & 16.9B & 16.7B & $16.2 \mathrm{~B}$ & I4.4B & I5.0B & $19.9 \mathrm{~A}$ & 0.0070 & 17.5a\# & $15.6 \mathrm{~b}$ & 0.0259 & \\
\hline
\end{tabular}

† Different lowercase letters indicate corn DM yield differences between crop rotations across tillage systems for a given year $(P \leq 0.05)$.

$\ddagger$ Different uppercase letters indicate corn DM yield differences among tillage systems across crop rotations for a given year $(P \leq 0.05)$.

$\S$ Data were not available for the 2006 growing season.

II Different uppercase letters indicate CV differences for corn DM yield among tillage systems across years and crop rotations $(P \leq 0.05)$.

\# Different lowercase letters indicate CV differences for corn DM yield between crop rotations across years and tillage systems $(P \leq 0.05)$.

27 yr (Table 6). Similar to corn, all tillage systems exhibited instances where it produced the least or similar to the least grain yield over multiple years. The one exception to this was MP, where it produced the least grain yield 1 yr (2000) and was greatest or equal to the greatest in the remaining 6 yr. For NT, soybean grain yield was the least in the initial three responsive years (initial $11 \mathrm{yr}$ of the study), but was the greatest or equal to the greatest in the final four responsive years (subsequent $16 \mathrm{yr}$ of the study). Soybean grain yield differed between crop rotations in 18 of $27 \mathrm{yr}$ (Table 6). In all responsive years, soybean grain yield with SC was greater than SS by 6 to $36 \%$ (0.2 to 0.7 $\left.\mathrm{Mg} \mathrm{ha}^{-1}\right)$. In the years where soybean grain yield did not differ between SC and SS, annual yield across rotations ranged from 1.6 to $3.4 \mathrm{Mg} \mathrm{ha}^{-1}$, which was 59 to $126 \%$ of the study mean, respectively. The CV (14.3\%) for soybean grain yield did not differ among tillage systems or crop rotations (Tables 1 and 6).

The regression of tillage treatment means on the annual means identified MP, NT, RT, and ST to be stable based on $\hat{\beta}$ not being different than one (Table 4). For $\mathrm{CH}$ and DK, $\hat{\beta}_{1}$ was different than one in both cases $(P=0.008$ and 0.0426 , respectively). For $\mathrm{CH}, \hat{\beta}_{1}$ was 0.910 , indicating that soybean grown under $\mathrm{CH}$ did not utilize weather conditions that were favorable for high-yielding production (favorable precipitation and/or moderate air temperatures). Conversely, $\beta_{1}$ was 1.06 for $\mathrm{DK}$, indicating that the yield potential of soybean grown with DK exceeded the annual mean under favorable conditions for grain production. When parameter estimates were compared among tillage systems, $\hat{\beta}_{1}$ with DK, MP, and ST was greater than $\mathrm{CH}$, while NT and RT were similar to all. For $\hat{\beta}_{0}, \mathrm{CH}$ was greater than DK and ST, while MP, NT, and RT were similar to all. Both SS and SC were classified as stable since $\hat{\beta}_{1}$ was not different than one for either crop rotation. No differences existed between SS and SC for either parameter estimate, indicating similar stability.

\section{DISCUSSION}

The response of corn and soybean production to management practices such as tillage system and crop rotation can be affected by environmental conditions (Porter et al., 1997; Wilhelm and Wortmann, 2004). For example, reduced-tillage or NT effects on corn growth and production can be affected by soil temperature. In environments that often experience cool soil temperatures, NT can inhibit plant emergence and earlyseason growth because of reduced solar radiation interception by the soil (Gupta et al., 1983; Swan et al., 1987). In comparison, NT has been shown to increase grain yields in semiarid environments, related to crop residues insulating the soil surface and reducing evaporative losses (Norwood and Currie, 1996; Klocke et al., 2009). The location of this study approximates geography where these two types of environments converge. Consequently, reduced-tillage or NT use did not result in a decisive grain yield advantage or disadvantage over the duration of the study when compared to more intensive tillage systems. For example, grain yield with NT was greatest or equal to the greatest in four of eight responsive years, but least 
Table 3. Response of corn grain yield and the coefficient of variation (CV) to tillage system (CH, chisel; DK, disk; MP, moldboard plow; NT, no-till; RT, ridge-tillage, ST, subsoil tillage) and crop rotation (CC, continuous corn; CS, corn phase of corn-soybean rotation) from 1986 to 2013.

\begin{tabular}{|c|c|c|c|c|c|c|c|c|c|c|}
\hline \multirow[b]{2}{*}{ Year } & \multicolumn{7}{|c|}{ Tillage system } & \multicolumn{3}{|c|}{ Crop rotation } \\
\hline & $\mathrm{CH}$ & DK & MP & NT & RT & ST & $F$ test & $\mathrm{CC}$ & CS & $F$ test \\
\hline & \multicolumn{6}{|c|}{$M g h^{-1}$} & $P>F$ & \multicolumn{2}{|c|}{$\longrightarrow \mathrm{Mg} \mathrm{ha}^{-1}-$} & $P>F$ \\
\hline 1986 & 7.0 & 6.7 & 7.4 & 7.2 & 7.0 & 6.9 & 0.8791 & $6.5 \mathrm{~b} t$ & $7.5 \mathrm{a}$ & 0.0065 \\
\hline 1987 & $5.9 A B \ddagger$ & $6.0 \mathrm{AB}$ & $6.6 \mathrm{~A}$ & $4.6 \mathrm{C}$ & $5.2 \mathrm{BC}$ & $5.8 \mathrm{AB}$ & 0.0306 & $5.1 b$ & $6.2 \mathrm{a}$ & 0.0023 \\
\hline 1988 & 5.6 & 5.8 & 6.7 & 6.1 & 5.8 & 5.9 & 0.5288 & $5.2 b$ & $6.8 \mathrm{a}$ & $<0.001$ \\
\hline 1989 & 7.5 & 8.1 & 7.9 & 7.2 & 7.7 & 7.9 & 0.7633 & 7.6 & 7.9 & 0.4199 \\
\hline 1990 & 7.9 & 7.5 & 7.9 & 6.9 & 7.2 & 7.2 & 0.5760 & $6.3 b$ & $8.6 a$ & $<0.001$ \\
\hline $199 \mid$ & 3.4 & 3.3 & 3.8 & 3.8 & 4.2 & 3.1 & 0.5393 & $2.4 \mathrm{~b}$ & $4.8 \mathrm{a}$ & $<0.001$ \\
\hline 1992 & 10.4 & 10.3 & 10.6 & 10.4 & 10.9 & 10.6 & 0.9391 & 10.4 & 10.7 & 0.3273 \\
\hline 1993 & 5.9 & 6.1 & 6.3 & 5.4 & 6.0 & 6.2 & 0.7467 & $5.3 b$ & $6.6 a$ & $<0.001$ \\
\hline 1994 & 8.7 & 8.8 & 9.4 & 7.8 & 8.8 & 8.6 & 0.2613 & $7.8 \mathrm{~b}$ & $9.6 a$ & $<0.001$ \\
\hline 1995 & 3.1 & 2.8 & 4.0 & 3.6 & 4.0 & 3.6 & 0.3231 & $2.3 b$ & $4.7 \mathrm{a}$ & $<0.001$ \\
\hline 1996 & 7.9 & 8.4 & 8.5 & 7.7 & 8.8 & 8.7 & 0.3045 & $7.6 \mathrm{~b}$ & $9.1 \mathrm{a}$ & $<0.001$ \\
\hline 1997 & $7.3 \mathrm{~B}$ & $6.7 \mathrm{~B}$ & $8.5 \mathrm{~A}$ & $6.7 \mathrm{~B}$ & $7.3 \mathrm{~B}$ & $6.5 B$ & 0.0075 & $6.4 b$ & $8.0 \mathrm{a}$ & $<0.001$ \\
\hline 1998 & $9.0 \mathrm{~B}$ & $9.2 \mathrm{~B}$ & $10.4 \mathrm{~A}$ & $8.5 B$ & $8.7 B$ & $9.0 \mathrm{~B}$ & 0.0217 & $8.2 b$ & $10.0 \mathrm{a}$ & $<0.001$ \\
\hline 1999 & 7.6 & 7.9 & 7.8 & 8.5 & 7.0 & 7.7 & 0.2059 & $6.7 b$ & $8.8 a$ & $<0.001$ \\
\hline 2000 & $6.0 \mathrm{~B}$ & $6.1 B$ & $3.7 C$ & $7.3 \mathrm{~A}$ & $4.5 \mathrm{C}$ & $6.0 \mathrm{~B}$ & $<0.001$ & 5.8 & 5.4 & 0.1333 \\
\hline 2001 & 9.0 & 8.9 & 8.5 & 9.4 & 8.2 & 8.7 & 0.4101 & $8.3 b$ & $9.3 a$ & 0.0025 \\
\hline 2002 & 1.2 & 0.7 & 1.5 & 2.3 & I.I & 0.9 & 0.0758 & $0.6 \mathrm{~b}$ & $2.0 \mathrm{a}$ & $<0.001$ \\
\hline 2003 & 7.4 & 7.1 & 7.7 & 7.4 & 7.4 & 6.1 & 0.7191 & 7.1 & 7.5 & 0.3023 \\
\hline 2004 & 11.2 & 11.7 & 11.3 & 11.7 & 12.2 & 10.5 & 0.0507 & 11.2 & 11.6 & 0.2030 \\
\hline 2005 & $3.8 \mathrm{C}$ & $5.0 \mathrm{AB}$ & $5.6 \mathrm{~A}$ & $5.8 \mathrm{~A}$ & $4.3 B C$ & 4.IBC & 0.004 & $3.6 \mathrm{~b}$ & $6.0 \mathrm{a}$ & $<0.001$ \\
\hline 2006 & 8.2 & 8.1 & 8.9 & 7.7 & 7.8 & 7.6 & 0.2007 & 8.0 & 8.1 & 0.8134 \\
\hline 2007 & 8.2ABC & $9.2 \mathrm{~A}$ & $8.5 \mathrm{AB}$ & $8.6 A B$ & $7.4 \mathrm{C}$ & $8.1 B C$ & 0.0331 & $8.0 \mathrm{~b}$ & $8.8 \mathrm{a}$ & 0.0168 \\
\hline 2008 & II.5AB & $11.6 \mathrm{AB}$ & $12.4 \mathrm{~A}$ & $10.5 B$ & $1 \mathrm{I} .4 \mathrm{AB}$ & $10.7 \mathrm{~B}$ & 0.0101 & $10.6 \mathrm{~b}$ & $12.1 \mathrm{a}$ & $<0.001$ \\
\hline 2009 & 9.8 & 9.2 & 10.0 & 10.2 & 8.8 & 10.0 & 0.0989 & $9.1 \mathrm{~b}$ & $10.2 \mathrm{a}$ & 0.0010 \\
\hline 2010 & 6.7ABC & $7.6 \mathrm{~A}$ & $5.8 \mathrm{C}$ & 7.0AB & $7.2 A B$ & $6.2 \mathrm{BC}$ & 0.01112 & $5.9 b$ & $8.0 \mathrm{a}$ & $<0.001$ \\
\hline 2011 & 8.4 & 9.4 & 10.0 & 9.2 & 8.7 & 9.5 & 0.0615 & 8.9 & 9.4 & 0.1457 \\
\hline 2012 & 2.6 & 2.9 & 3.4 & 3.0 & 2.7 & 2.4 & 0.5621 & 2.5 & 3.1 & 0.1148 \\
\hline 2013 & 8.2 & 8.8 & 9.7 & 9.0 & 9.0 & 9.0 & 0.1867 & 9.3 & 8.6 & 0.0568 \\
\hline Trt. mean & 7.1 & 7.3 & 7.6 & 7.3 & 7.1 & 7.1 & - & 6.7 & 7.8 & - \\
\hline CV (\%) & 15.3 & 15.4 & 15.1 & 15.0 & 15.1 & 17.3 & 0.4750 & I7.7a & $13.6 \mathrm{~b}$ & $<0.001$ \\
\hline
\end{tabular}

† Different lowercase letters indicate corn grain yield differences between crop rotations across tillage systems for a given year $(P \leq 0.05)$.

$\ddagger$ Different uppercase letters indicate corn grain yield differences among tillage systems across crop rotations for a given year $(P \leq 0.05)$.

$\S$ Different lowercase letters indicate $C V$ differences between crop rotations across tillage systems and years $(P \leq 0.05)$.

or equal to the least in the other four (Table 3). In comparison, grain yield with MP was greatest or equal to the greatest in 6 of $8 \mathrm{yr}$, and the least or equal to the least in $2 \mathrm{yr}$. These inconsistent responses combined with the lack of differences among tillage systems in $71 \%$ of the cropping years indicate that grain yield can often be maximized if managed properly, regardless of tillage selection. Conversely, NT adoption did not consistently result in suppressed corn grain yield, which can be associated with NT corn production (Pedersen and Lauer, 2003; Vetsch et al., 2007; Boomsma et al., 2010). Only 1 yr occurred where NT grain yield was not the greatest or similar to the greatest in the final $15 \mathrm{yr}$ of the study (Table 3). In the previous $13 \mathrm{yr}$, grain yield with NT was less than at least one other tillage system in $3 \mathrm{yr}$ and similar in the remaining. This suggests there may be a lag period until a grain yield advantage or lack of yield reduction associated with $\mathrm{NT}$ is consistently detectable.

Similarities among tillage systems were further evident by the grain yield stability analysis (Table 4). All tillage systems, when averaged across crop rotations, were classified to be stable as indicated by $\hat{\beta}_{1}$ (slope) estimates that were not different than one (Table 4). When pairwise comparisons of tillage systems were made, differences existed between DK and NT, as $\hat{\beta}_{0}$ of NT was greater than DK, while the inverse was true for $\hat{\beta}_{1}$. This suggests NT systems may exhibit greater yield stability in years with non-optimal yield potential, but DK systems may be more productive than NT as yield potential increases.

Crop rotation influenced corn grain yield more than tillage system (68 and $29 \%$ of cropping years, respectively) (Table 3). In all 19 responsive years, corn grain yield in CS was 10 to $221 \%$ greater than CC. Corn grain yield advantages of CS over CC are well-documented (Pedersen and Lauer, 2003; Drury and Tan, 1994; West et al., 1996; Gentry et al., 2013). Explanation for this response include less residue coverage following soybean than corn and subsequent warmer soil temperatures (Boomsma et al., 2010), increased $\mathrm{N}$ availability from symbiotic fixation by the previous soybean crop (Gentry et al., 2001; Varvel and Wilhelm, 2003), and less N immobilization 
Table 4. Parameter estimates, $r^{2}$ values, tests of model significance, and tests of grain yield stability $\left(\hat{\beta}_{1}=I\right)$ of corn and soybean to tillage system $(\mathrm{CH}$, chisel; DK, disk; MP, moldboard plow; NT, no-till; RT, ridge-tillage, ST, subsoil tillage) and crop rotation (CC, continuous corn; CS, corn phase of corn-soybean-rotation; SS, continuous soybean; SC, soybean phase of corn-soybean rotation) treatments.

\begin{tabular}{|c|c|c|c|c|c|c|c|}
\hline Crop & Tillage system & Crop rotation & $\hat{\beta}_{0}$ & $\hat{\beta}_{1}$ & $r^{2}$ & Model significance & $\hat{\beta}_{1}=1$ \\
\hline & & & $M$ & & & $P>F$ & $P>F$ \\
\hline \multirow[t]{8}{*}{ Corn } & $\mathrm{CH}$ & & $-0.206 \mathrm{AB} \dagger$ & I.0IAB & 0.98 & $<0.001$ & 0.7582 \\
\hline & DK & & $-0.299 B$ & $1.05 \mathrm{~A}$ & 0.98 & $<0.001$ & 0.1230 \\
\hline & MP & & $0.221 \mathrm{AB}$ & $1.02 \mathrm{AB}$ & 0.94 & $<0.001$ & 0.6788 \\
\hline & NT & & $0.616 \mathrm{~A}$ & $0.92 \mathrm{~B}$ & 0.94 & $<0.001$ & 0.0901 \\
\hline & RT & & $-0.164 A B$ & $1.00 A B$ & 0.96 & $<0.001$ & 0.9275 \\
\hline & ST & & $-0.146 \mathrm{AB}$ & $1.00 A B$ & 0.98 & $<0.001$ & 0.8619 \\
\hline & & $\mathrm{CC}$ & $-0.952 b \ddagger$ & $1.05 \mathrm{a}$ & 0.98 & $<0.001$ & 0.1413 \\
\hline & & CS & $0.947 a$ & $0.947 b$ & 0.96 & $<0.001$ & 0.1304 \\
\hline \multirow[t]{8}{*}{ Soybean } & $\mathrm{CH}$ & & $0.204 \mathrm{~A}$ & $0.910 \mathrm{~B}$ & 0.97 & $<0.001$ & 0.0080 \\
\hline & DK & & $-0.178 \mathrm{~B}$ & $1.06 \mathrm{~A}$ & 0.98 & $<0.001$ & 0.0426 \\
\hline & MP & & $-0.045 A B$ & $\mathrm{I} .04 \mathrm{~A}$ & 0.93 & $<0.001$ & 0.4806 \\
\hline & NT & & $0.050 \mathrm{AB}$ & $0.990 \mathrm{AB}$ & 0.93 & $<0.001$ & 0.8488 \\
\hline & RT & & $0.048 \mathrm{AB}$ & $0.967 A B$ & 0.95 & $<0.001$ & 0.4874 \\
\hline & ST & & $-0.07 \mid \mathrm{B}$ & $1.03 \mathrm{~A}$ & 0.98 & $<0.001$ & 0.3264 \\
\hline & & SS & $-0.044 a$ & $0.966 a$ & 0.98 & $<0.001$ & 0.2635 \\
\hline & & SC & $0.079 \mathrm{a}$ & $1.03 \mathrm{a}$ & 0.97 & $<0.001$ & 0.3563 \\
\hline
\end{tabular}

† Different uppercase letters indicate differences among tillage systems across crop rotations $(P \leq 0.05)$.

$\ddagger$ Different lowercase letters indicate differences between crop rotations across tillage systems $(P \leq 0.05)$.

Table 5. Soybean DM production and the coefficient of variation (CV) as affected by tillage system (CH, chisel; DK, disk; MP, moldboard plow; NT, no-till; RT, ridge-tillage, ST, subsoil tillage) and crop rotation (SS, continuous soybean; SC, soybean phase of corn-soybean rotation) from 1997 to 2013.

\begin{tabular}{|c|c|c|c|c|c|c|c|c|c|c|}
\hline \multirow[b]{2}{*}{ Year } & \multicolumn{6}{|c|}{ Tillage system } & \multicolumn{3}{|c|}{ Crop rotation } & \multirow[b]{2}{*}{ Annual mean } \\
\hline & $\mathrm{CH}$ & DK & MP & NT & RT & ST & SS & SC & $F$ test & \\
\hline & \multicolumn{6}{|c|}{$-\mathrm{Mg} \mathrm{DM} \mathrm{ha}^{-\mathrm{I}}$} & \multicolumn{2}{|c|}{ - Mg DM ha-1 - } & $P>F$ & Mg DM ha ${ }^{-1}$ \\
\hline 1997 & 5.7 & 5.6 & 6.2 & 5.6 & 5.4 & 5.5 & $5.4 \mathrm{~b} \dagger$ & $5.9 a$ & 0.0111 & 5.7 \\
\hline 1998 & 6.4 & 6.7 & 6.8 & 7.1 & 7.0 & 6.7 & $6.5 b$ & $7.1 \mathrm{a}$ & 0.0054 & 6.8 \\
\hline 1999 & 5.1 & 5.1 & 5.7 & 5.7 & 5.6 & 5.8 & $5.3 b$ & $5.8 \mathrm{a}$ & 0.0210 & 5.5 \\
\hline 2000 & 4.1 & 4.1 & 3.3 & 5.0 & 3.8 & 4.2 & $3.4 \mathrm{~b}$ & $4.8 \mathrm{a}$ & $<0.001$ & 4.1 \\
\hline 2001 & 5.9 & 6.3 & 6.2 & 7.3 & 6.2 & 6.1 & $5.8 b$ & $6.8 \mathrm{a}$ & $<0.001$ & 6.3 \\
\hline 2002 & 3.9 & 3.7 & 3.8 & 4.7 & 3.9 & 4.0 & $3.5 b$ & $4.6 \mathrm{a}$ & $<0.001$ & 4.0 \\
\hline 2003 & 4.9 & 4.9 & 5.3 & 5.6 & 4.9 & 4.7 & $4.5 b$ & $5.6 \mathrm{a}$ & $<0.001$ & 5.1 \\
\hline 2004 & 6.9 & 7.5 & 7.7 & 7.1 & 6.5 & 6.7 & $6.6 \mathrm{~b}$ & $7.5 \mathrm{a}$ & $<0.001$ & 7.0 \\
\hline 2005 & 6.2 & 6.2 & 6.5 & 7.1 & 6.3 & 6.4 & $6.2 b$ & $6.7 \mathrm{a}$ & 0.0064 & 6.4 \\
\hline \multicolumn{11}{|l|}{$2006 \ddagger$} \\
\hline 2007 & 6.9 & 7.5 & 7.0 & 7.5 & 7.0 & 7.4 & $6.9 b$ & $7.5 \mathrm{a}$ & 0.0063 & 7.2 \\
\hline 2008 & 7.2 & 7.3 & 7.2 & 7.6 & 7.4 & 7.3 & $6.9 b$ & $7.7 \mathrm{a}$ & 0.0003 & 7.3 \\
\hline 2009 & 5.5 & 6.1 & 6.6 & 6.6 & 5.9 & 6.0 & $5.7 b$ & $6.6 a$ & $<0.001$ & 6.1 \\
\hline 2010 & 6.3 & 6.7 & 6.8 & 7.1 & 6.5 & 6.7 & 6.5 & 6.8 & 0.1420 & 6.7 \\
\hline 2011 & 7.1 & 6.9 & 7.3 & 7.1 & 7.1 & 7.3 & 7.0 & 7.3 & 0.1326 & 7.1 \\
\hline 2012 & 4.3 & 4.3 & 4.6 & 4.7 & 4.3 & 4.4 & 4.3 & 4.6 & 0.2125 & 4.4 \\
\hline 2013 & 4.3 & 5.0 & 5.5 & 5.0 & 4.4 & 5.1 & $4.3 b$ & $5.5 \mathrm{a}$ & $<0.001$ & 4.9 \\
\hline Trt. mean & $5.7 C \S$ & $5.9 \mathrm{~B}$ & $6.0 \mathrm{~B}$ & $6.3 \mathrm{~A}$ & $5.8 \mathrm{BC}$ & $5.9 \mathrm{~B}$ & 5.5 & 6.3 & & 5.9 \\
\hline CV (\%) & I3.5BCף & I5.5AB & $16.2 \mathrm{~A}$ & $11.8 \mathrm{C}$ & $13.9 \mathrm{ABC}$ & I4.0ABC & 14.5 & 13.8 & 0.3130 & \\
\hline
\end{tabular}

$\dagger$ Different lowercase letters indicate soybean DM yield differences between crop rotations across tillage systems for a given year $(P \leq 0.05)$.

$\ddagger$ Data were not available for the 2006 growing season.

$\S$ Different uppercase letters indicate soybean DM yield differences among tillage systems across years and crop rotations $(P \leq 0.05)$.

I Different uppercase letters indicate CV differences of soybean DM yield among tillage systems across years and crop rotations $(P \leq 0.05)$. 
Table 6. Response of soybean grain yield and the coefficient of variation (CV) to tillage system (CH, chisel; DK, disk; MP, moldboard plow; NT, no-till; RT, ridge-tillage, ST, subsoil tillage) and crop rotation (SS, continuous soybean; SC, soybean phase of corn-soybean rotation) from 1986 to 2013 .

\begin{tabular}{|c|c|c|c|c|c|c|c|c|c|c|}
\hline \multirow[b]{2}{*}{ Year } & \multicolumn{7}{|c|}{ Tillage system } & \multicolumn{3}{|c|}{ Crop rotation } \\
\hline & $\mathrm{CH}$ & DK & $M P$ & NT & RT & ST & $F$ test & SS & SC & $F$ test \\
\hline & \multicolumn{6}{|c|}{$\mathrm{Mg} \mathrm{ha}^{-1}$} & $P>F$ & \multicolumn{2}{|c|}{$-\mathrm{Mg} \mathrm{ha}^{-1}-$} & $P>F$ \\
\hline 1986 & 4.1 & 4.4 & 4.4 & 4.4 & 4.3 & 4.6 & 0.4509 & 4.Ibt & $4.7 \mathrm{a}$ & $<0.001$ \\
\hline 1987 & 2.5 & 2.4 & 2.7 & 2.5 & 2.3 & 2.4 & 0.5313 & 2.5 & 2.5 & 0.7996 \\
\hline 1988 & 2.9 & 2.9 & 2.5 & 2.8 & 2.9 & 2.8 & 0.4611 & $2.7 b$ & $3.0 \mathrm{a}$ & 0.0246 \\
\hline 1989 & 2.3 & 2.1 & 2.5 & 2.1 & 2.1 & 1.9 & 0.1478 & $2.0 \mathrm{~b}$ & $2.3 a$ & 0.0337 \\
\hline 1990 & $2.3 A \ddagger$ & $2.2 \mathrm{~A}$ & $2.2 \mathrm{~A}$ & I.7B & $2.3 \mathrm{~A}$ & $2.3 \mathrm{~A}$ & 0.0440 & 2.2 & 2.2 & 0.4584 \\
\hline 1991 & 2.7 & 2.6 & 2.3 & 2.6 & 2.4 & 2.5 & 0.3479 & 2.5 & 2.5 & $0.7 \mid 43$ \\
\hline 1992 & 3.4 & 3.4 & 3.4 & 3.5 & 3.5 & 3.4 & 0.9179 & 3.4 & 3.4 & 0.8308 \\
\hline 1993 & $2.5 \mathrm{~A}$ & $2.5 \mathrm{~A}$ & $2.5 \mathrm{~A}$ & $1.9 \mathrm{~B}$ & $2.7 \mathrm{~A}$ & $2.3 \mathrm{~A}$ & 0.0065 & 2.4 & 2.4 & 0.7899 \\
\hline 1994 & 3.1 & 3.4 & 3.3 & 3.1 & 3.4 & 3.3 & 0.4916 & $3.1 b$ & $3.4 \mathrm{a}$ & 0.0496 \\
\hline 1995 & 1.6 & 1.6 & 1.6 & 1.5 & 1.9 & 1.7 & 0.6059 & 1.6 & 1.7 & 0.4717 \\
\hline 1996 & $2.5 \mathrm{AB}$ & $2.5 \mathrm{~B}$ & $2.8 \mathrm{~A}$ & $2.1 \mathrm{C}$ & $2.3 \mathrm{BC}$ & $2.6 \mathrm{AB}$ & 0.0107 & $2.2 b$ & $2.8 \mathrm{a}$ & $<0.001$ \\
\hline 1997 & 2.2 & 2.2 & 2.4 & 2.1 & 2.1 & 2.1 & 0.5076 & $2.0 \mathrm{~b}$ & $2.3 a$ & 0.0073 \\
\hline 1998 & 3.1 & 3.2 & 3.1 & 3.3 & 3.4 & 3.3 & 0.4192 & 3.2 & 3.3 & 0.1560 \\
\hline 1999 & 2.5 & 2.5 & 2.8 & 2.7 & 2.6 & 2.8 & 0.3144 & $2.5 \mathrm{~b}$ & $2.8 \mathrm{a}$ & 0.0038 \\
\hline 2000 & I.8A & $1.7 A B$ & I.3B & $2.0 \mathrm{~A}$ & $1.5 \mathrm{AB}$ & $1.7 A B$ & 0.0252 & $\mathrm{I} .4 \mathrm{~b}$ & $1.9 \mathrm{a}$ & $<0.001$ \\
\hline 2001 & 2.3 & 2.1 & 2.3 & 2.5 & 2.0 & 2.2 & 0.2460 & $2.0 \mathrm{~b}$ & $2.4 a$ & $<0.001$ \\
\hline 2002 & 1.4 & 1.2 & 1.4 & 1.7 & 1.4 & 1.4 & 0.3867 & $1.2 \mathrm{~b}$ & $1.6 \mathrm{a}$ & 0.0021 \\
\hline 2003 & 2.2 & 2.1 & 2.4 & 2.6 & 2.2 & 2.1 & 0.1027 & $2.0 \mathrm{~b}$ & $2.5 \mathrm{a}$ & $<0.001$ \\
\hline 2004 & $4.0 B C$ & $4.2 \mathrm{AB}$ & $4.4 \mathrm{~A}$ & 4.I $A B$ & $3.7 C$ & $3.9 B C$ & 0.0070 & $3.7 b$ & $4.3 a$ & $<0.001$ \\
\hline 2005 & 3.0 & 3.1 & 2.9 & 3.4 & 2.8 & 3.0 & 0.0573 & $2.8 \mathrm{~b}$ & $3.3 a$ & $<0.001$ \\
\hline \multicolumn{11}{|l|}{$2006 \S$} \\
\hline 2007 & 3.5 & 3.7 & 3.4 & 3.6 & 3.4 & 3.5 & 0.4691 & $3.4 b$ & $3.6 \mathrm{a}$ & 0.0172 \\
\hline 2008 & 3.4 & 3.5 & 3.5 & 3.4 & 3.5 & 3.3 & 0.8756 & $3.2 b$ & $3.7 \mathrm{a}$ & $<0.001$ \\
\hline 2009 & $2.9 \mathrm{C}$ & $3.2 A B C$ & $3.5 \mathrm{~A}$ & $3.4 \mathrm{AB}$ & $3.0 \mathrm{~B}$ & $3.3 A B$ & 0.0211 & $3.0 \mathrm{~b}$ & $3.4 \mathrm{a}$ & $<0.001$ \\
\hline 2010 & 2.7 & 2.7 & 2.9 & 2.8 & 2.8 & 2.8 & $0.936 I$ & 2.8 & 2.8 & 0.9269 \\
\hline 2011 & 3.1 & 2.9 & 3.5 & 3.1 & 3.1 & 3.3 & 0.0877 & 3.1 & 3.2 & 0.1574 \\
\hline 2012 & 2.0 & 2.0 & 2.1 & 2.1 & 2.2 & 2.1 & 0.8311 & $2.0 \mathrm{~b}$ & $2.2 \mathrm{a}$ & 0.0496 \\
\hline 2013 & $2.3 \mathrm{~B}$ & $2.5 \mathrm{AB}$ & $2.8 \mathrm{~A}$ & $2.5 \mathrm{AB}$ & $2.2 \mathrm{~B}$ & $2.5 \mathrm{AB}$ & 0.0124 & $2.1 b$ & $2.8 \mathrm{a}$ & $<0.001$ \\
\hline Trt. mean & 2.7 & 2.7 & 2.8 & 2.7 & 2.7 & 2.7 & & 2.6 & 2.9 & \\
\hline $\mathrm{CV}, \%$ & 14.0 & 15.2 & 15.1 & 14.5 & 13.6 & 13.5 & 0.6811 & 14.9 & 13.8 & 0.0736 \\
\hline
\end{tabular}

† Different lowercase letters indicate soybean grain yield differences between crop rotations across tillage systems for a given year $(P \leq 0.05)$. $\ddagger$ Different uppercase letters indicate soybean grain yield differences among tillage systems across crop rotations for a given year $(P \leq 0.05)$.

$\S$ Data were not available for the 2006 growing season.

by soybean residue than that for corn (Green and Blackmer, 1995; Gentry et al., 2001). Plant-to-plant emergence and growth variability, which can be affected by surface residue coverage and thickness, results in greater overall yield variability and subsequent yield reductions (Martin et al., 2005; Boomsma et al., 2010). While not directly measured, it is feasible that residue remaining on the soil surface in CC inhibited corn plant emergence and early-season growth.

Although corn DM yield with CS was greater than CC in $75 \%$ of cropping years (Table 2), the response of grain yield to crop rotation was slightly less consistent (68\% of cropping years) (Table 3). The remaining $9 \mathrm{yr}$ where crop rotation did not have an effect, grain yield across crop rotations was $\geq 7.3 \mathrm{Mg} \mathrm{ha}^{-1}$ in all but $2 \mathrm{yr}$, which was at least equal to the study mean $\left(7.2 \mathrm{Mg} \mathrm{ha}^{-1}\right)$. The corn grain yield advantage of CS over CC regressed on CC grain yield further illustrates this interaction, with corn grain yield gains from CS decreasing in growing seasons with favorable growing conditions (Fig. 4A). Specifically, the regression predicted a $0.15 \mathrm{Mg} \mathrm{ha}^{-1}$ decrease in the CS grain yield advantage for each $\mathrm{Mg} \mathrm{ha}^{-1}$ increase in CC grain yield $(P=0.02)$. Based on the regression, the CS grain yield advantage would be negated at a mean CC yield of 14.5 $\mathrm{Mg} \mathrm{ha}^{-1}$. This response agrees with Porter et al. (1997) in Minnesota and Wisconsin and Pikul et al. (2005) in South Dakota. Initially, this yield response seems counterintuitive based on $\mathrm{N}$ demand. As yield potential increases, so does the N requirement (Stanford, 1973; Vanotti and Bundy, 1994). Furthermore, there may be greater available $\mathrm{N}$ for the subsequent crop with CS resulting from the additional legume $\mathrm{N}$ credit, which can range from 39 to $65 \mathrm{~kg} \mathrm{~N} \mathrm{ha}^{-1}$ in Nebraska (Varvel and Wilhelm, 2003; Shapiro et al., 2008). However, the observed response in Fig. 4A indicates that the influence of the legume $\mathrm{N}$ credit on the $\mathrm{CS}$ yield advantage may decrease as yield potential increases. Since water and solar radiation were likely not limiting, it is also probable that $\mathrm{N}$ mineralization in these particular settings is quite rapid since soil conditions were favorable. Gentry et al. (2001) concluded that both the decrease in net $\mathrm{N}$ mineralization with $\mathrm{CC}$ and $\mathrm{N}$ from symbiotic 


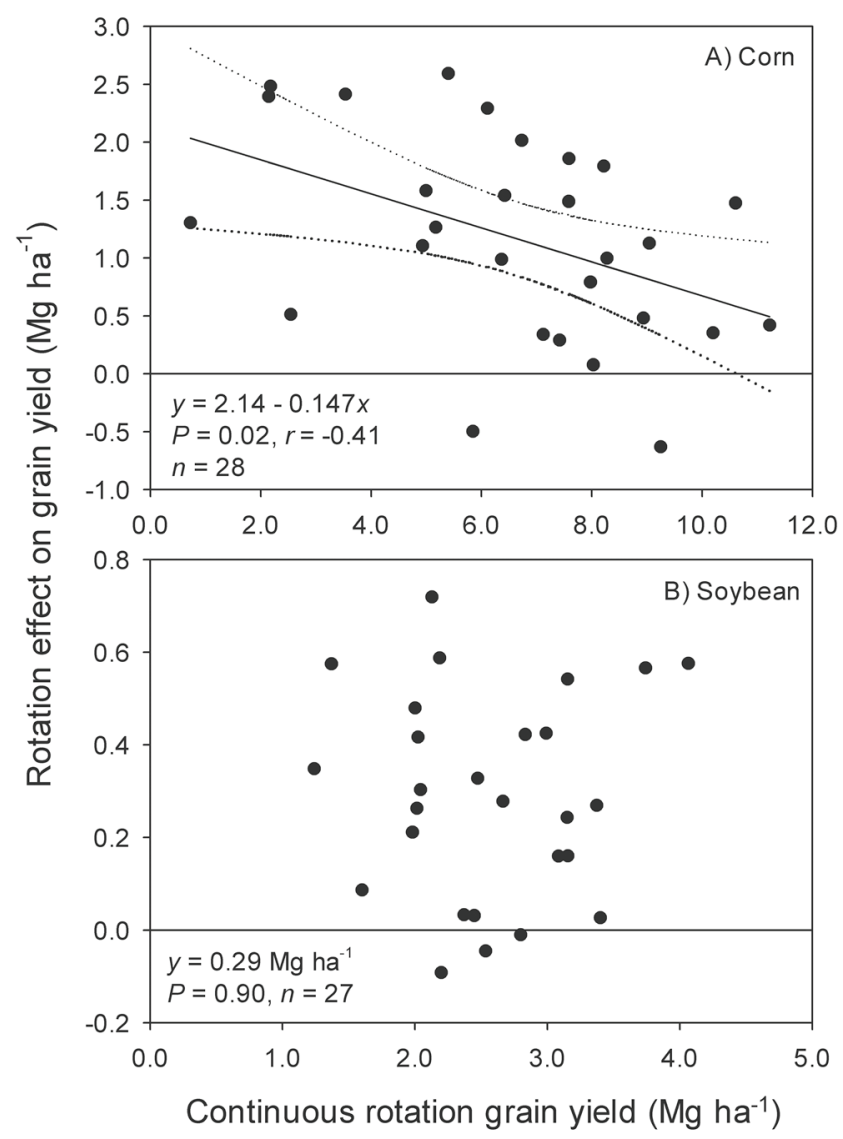

Fig. 4. Relationship between the yield advantage of crop rotation and continuous grain yield for $(A)$ corn and $(B)$ soybean. Dashed lines indicate $95 \%$ confidence interval.

fixation with CS contribute to the overall soybean $\mathrm{N}$ credit. Although Gentry et al. (2001) found that net mineralization in CC was less than with CS during critical growth stages of $\mathrm{N}$ uptake (V10-R2), we hypothesize that decreasing differences in grain yield between CS and CC as yield increased were attributed to either (i) net $\mathrm{N}$ mineralization rates that did not differ between crop rotations or (ii) $\mathrm{N}$ mineralization in CC is at a rate that satisfies crop demand in years with favorable growing conditions. Additional work is needed to test these hypotheses in high-yielding environments with minimal stress.

The response of soybean DM yield to tillage system was consistent across years (Table 1). Soybean DM yield with NT was greater than all other tillage systems by $\geq 5 \%$ (Table 5 ). There are several possible explanations for this response. First, potentially cooler soil temperatures related to returned and unincorporated corn residues from the previous growing season did not adversely affect early-season soybean growth. Second, planting dates used in this study (early to mid-May) generally occurred after these periods of growth-limiting conditions (attributed to soil temperature). Finally, greater soil water availability may have been present in the NT treatment during early to mid-season growth, as others have documented greater soil water with NT in semiarid environments (Norwood, 1999; Baumhardt and Jones, 2002). Simultaneous evaluation of soil temperature and soil water content during the growing season is needed to determine the mechanism(s) contributing to this response. The response of soybean grain yield to tillage system differed among years (Table 1). No unanimous tillage system ranking for soybean grain yield existed across crop rotations, and tillage system did not affect soybean grain yield in $74 \%$ of cropping years (Table 6). All tillage systems, with the exception of $\mathrm{CH}$, were regarded as being at stable (Table 4). With $\mathrm{CH}, \hat{\beta}_{1}$ was less than one, indicating its inability to utilize growing conditions conducive for high-yield grain production.

One important, and notable, response was that soybean grain yield with NT was greatest or equal to the greatest in four of seven responsive years (Table 6). This indicates that the observed total DM responses observed with NT across years were not an explicit function of grain yield increases. In a nearby study by Dickey et al. (1994), soybean grain yield with NT was greatest or equal to the greatest each year of a 5 -yr study in a grain sorghum-soybean rotation. It should also be noted that the instances in this study where soybean with NT had below average grain yield occurred within the initial $11 \mathrm{yr}$ of this study for SC (Table 6). This suggests that there may be a lag period in soybean grain yield improvements associated with NT. Overall, these results indicate that selection of NT combined with recommended planting dates for the region can result in stable soybean grain yields that are equal to, if not greater than, yields obtained with other tillage systems. However, yield increases may not be consistently be apparent within the initial years of NT adoption.

Soybean DM production was greater with SC than with SS across all tillage systems in 13 of $16 \mathrm{yr}$ (Table 5). This is in agreement with Peterson and Varvel (1989a), who observed greater DM production when soybean was planted in rotation than when planted continuously. Soybean grain yield was greater with SC than with SS in $67 \%$ of cropping years, regardless of tillage system, and similar between crop rotations in the remaining years (Table 6). Greater grain yields with SC over SS are in agreement with Peterson and Varvel (1989a), Adee et al. (1994), and Pedersen and Lauer (2003). This indicates soybean grain yield should be expected to be similar or greater when grown in rotation than when continuously. No significant relationship existed between the yield advantage of SC and SS grain yield (Fig. 4B). This differs from Porter et al. (1997), who found that this yield advantage in SC decreased as SS grain yield increased. Despite soybean grain yield with SC often being similar to, if not greater, than with SS, no stability differences existed between SC and SS for any tillage system (Table 4). This suggests that the rotation effect may have more influence on the yield stability of corn than on soybean.

\section{CONCLUSIONS}

Identifying crop and soil management practices that are productive and resilient against abnormal or extreme weather conditions is important for rainfed agroecosystems. Tillage and crop rotation had varying degrees of influence on corn and soybean production, with responses often differing among years. No discernable corn grain yield advantage existed for any tillage system. In addition, all tillage systems were found to be stable. This indicates that corn production can be high-yielding and stable when well managed, regardless of tillage system. Corn grain yield with NT resulted in consistent, high grain yields in 15 of the final $16 \mathrm{yr}$ of the study, suggesting a lag period may exist before consistent yield advantages associated with NT may be detectable. Crop rotation demonstrated a greater effect on corn 
grain yield than that with tillage system, as grain yield with CS was greater than CC in $68 \%$ of cropping years, and similar in the remaining years. This response may be attributed to more favorable soil conditions for early-season corn growth, less $\mathrm{N}$ immobilization by soybean residue in CS, or increased $\mathrm{N}$ availability via the legume $\mathrm{N}$ credit. It was also observed that the yield advantage associated with CS decreased as CC yield increased. Use of NT in SC resulted in soybean grain yields that were greatest or equal to the greatest in the final $16 \mathrm{yr}$ of the study. This again indicates a lag period may exist until yield benefits associated with NT are measurable. The influence of crop rotation was also apparent for soybean grain yield, as grain yield with SC was greater than SS 67\% of cropping years, and similar in the remaining years. Unlike corn, no discernable relationship existed between the yield advantage associated with SC and SS grain yield across years, and the stability of soybean grain yield did not differ between crop rotations. These results indicate that corn and soybean grain grown in rotation will often produce grain yields that are at least similar, if not greater, than when grown continuously. Finally, yield advantages associated with NT may not be consistently visible until adoption is longer-term $(\geq 1 \mathrm{yr}$ in this study). The responses of corn and soybean grain production to NT in this study clearly illustrate the importance of long-term experiments in identifying such trends.

\section{ACKNOWLEDGMENTS}

This study is supported by the Agriculture Research Service under the Greenhouse Gas Reduction through Agricultural Carbon Enhancement network (GRACEnet). Mention of commercial names does not imply recommendation or endorsement by the USDA. The authors thank Lloyd Mielke for his establishment of the study and Drs. Gary Varvel and Wally Wilhelm for their support of the study throughout its duration. The authors also acknowledge Kathy Yeater for her statistical consultation and suggestions. This study would also not be possible without the contributions of Steve Swanson, Paul Koerner, Nate Mellor, Robert Harrison, Chris Bauer, Aaron Bereuter, Dennis Francis, Ken Richards, Kim Ruwe, Jeff Shanle, numerous graduate students, and many undergraduate student employees. The USDA is an equal opportunity employer and provider.

\section{REFERENCES}

Abendroth, L.J., R.W. Elmore, M.J. Boyser, and S.K. Marlay. 2011. Corn growth and development. PMR 1009. Iowa State Univ. Ext., Ames.

Abid, M., and R. Lal. 2008. Tillage and drainage impact on soil quality I. Aggregate stability, carbon, and nitrogen pools. Soil Tillage Res. 100:89-98. doi:10.1016/j.still.2008.04.012

Adee, E.A., E.S. Oplinger, and C.R. Grau. 1994. Tillage, rotation sequence, and cultivar influences on brown stem rot and soybean yield. J. Prod. Agric. 7:341-347. doi:10.2134/jpa1994.0341

Alley, W.M. 1984. The Palmer Drought Severity Index: Limitations and assumptions. J. Clim. Appl. Meteorol. 23:1100-1109. doi:10.1175/1520-0450(1984)0232.0.CO;2

Arshad, M.A., A.J. Franzluebbers, and R.H. Azooz. 1999. Components of surface soil structure under conventional and no-tillage in northwestern Canada. Soil Tillage Res. 53:41-47. doi:10.1016/ S0167-1987(99)00075-6

Baldock, J.O., J.L. Hedtcke, J.L. Posner, and J.A. Hall. 2014. Organic and conventional production systems in the Wisconsin integrated cropping systems trial: III. Yield trends. Agron. J. 106:1509-1522. doi:10.2134/agronj14.0004
Baumhardt, R.L., and O.R. Jones. 2002. Residue management and tillage effects on soil-water storage and grain yield of dryland wheat and sorghum for a clay loam in Texas. Soil Tillage Res. 68:71-82. doi:10.1016/S0167-1987(02)00097-1

Becker, H.C., and J. Léon. 1988. Stability analysis in plant breeding. Plant Breed. 101:1-23. doi:10.1111/j.1439-0523.1988.tb00261.x

Blanco-Canqui, H., M.M. Mikha, J.G. Benjamin, L.R. Stone, A.J. Schlegel, D.J. Lyon et al. 2009. Regional study of no-till impacts on near-surface aggregate properties that influence soil erodibility. Soil Sci. Soc. Am. J. 73:1361-1368. doi:10.2136/sssaj2008.0401

Boomsma, C.R., J.B. Santini, T.D. West, J.C. Brewer, L.M. McIntyre, and T.J. Vyn. 2010. Maize grain yield responses to plant height variability resulting from crop rotation and tillage system in a longterm experiment. Soil Tillage Res. 106:227-240. doi:10.1016/j. still.2009.12.006

Coulter, J.A., C.C. Sheaffer, D.L. Wyse, M.J. Haar, P.M. Porter, S.R. Quiring, and L.D. Klossner. 2011. Agronomic performance of cropping systems with contrasting crop rotations and external inputs. Agron. J. 103:182-192. doi:10.2134/agronj2010.0211

Dickey, E.C., P.J. Jasa, and R.D. Grisso. 1994. Long term tillage effects on grain yield and soil properties in a soybean/grain sorghum rotation. J. Prod. Agric. 7:465-470. doi:10.2134/jpa1994.0465

Drinkwater, L.E. 2002. Cropping systems research: Reconsidering agricultural experimental approaches. Horttechnology 12:355-361.

Drury, C.F., and C.S. Tan 1994. Long-term (35 years) effects of fertilization, rotation and weather on corn yields. Can. J. Plant Sci. 75:355362. doi:10.4141/cjps95-060

Ferguson, R.B., G.W. Hergert, and E.J. Penas. 2000a. Corn. In: R.B. Ferguson and K.M. De Groot, editors, Nutrient management for agronomic crops in Nebraska. EC155. Univ. of Nebraska, Lincoln. p. $75-83$.

Ferguson, R.B., E.J. Penas, and W.B. Stevens. Soybean. 2000b. Corn. In: R.B. Ferguson and K.M. De Groot, editors, Nutrient management for agronomic crops in Nebraska. EC155. Univ. of Nebraska, Lincoln. p. 121-125.

Finlay, K.W., and G.N. Wilkinson. 1963. The analysis of adaptation in a plant-breeding programme. Aust. J. Agric. Res. 14:742-754. doi:10.1071/AR9630742

Gentry, L.E., F.E. Below, M.B. David, and J.A. Bergerou. 2001. Source of soybean N credit in maize production. Plant Soil 236:175-184. doi:10.1023/A:1012707617126

Gentry, L.F., M.L. Ruffo, and F.E. Below. 2013. Identifying factors controlling the continuous corn yield penalty. Agron. J. 105:295-303. doi:10.2134/agronj2012.0246

Green, C.J., and A.M. Blackmer. 1995. Residue decomposition effects on nitrogen availability to corn following corn or soybean. Soil Sci. Soc. Am. J. 59:1065-1070. doi:10.2136/ sssaj1995.03615995005900040016x

Griffith, D.R., and N.C. Wollenhaupt. 1994. Crop residue management strategies for the Midwest. In: J.L. Hatfield and B.A. Stewart, editors, Crop residue management. Advances in soil science. Lewis Publ., Boca Raton, FL. p. 15-36.

Grover, K.K., H.D. Karsten, and G.W. Roth. 2009. Corn grain yields and yield stability in four long-term cropping systems. Agron. J. 101:940-946. doi:10.2134/agronj2008.0221x

Gupta,S.C., W.E. Larson, and D.R.Linden. 1983. Tillage and surface residue effects on soil upper-boundary temperature. Soil Sci. Soc. Am.J. 47:1212-1248. doi:10.2136/sssaj1983.03615995004700060030x

Hildebrand, P.E. 1984. Modified stability analysis of farmer managed, on-farm trials. 1984. Agron. J. 76:271-274. doi:10.2134/agronj19 $84.00021962007600020023 x$

Horowitz, J., R. Ebel, and K. Ueda. 2010. No-till farming is a growing practice. Bull. no. 70. USDA-ERS, Washington, DC.

Klocke, N.L., R.S. Currie, and R.M. Aiken. 2009. Soil water evaporation and crop residues. Trans. ASABE 52:103-110. doi:10.13031/2013.25951 
Lal, R. 2004. Soil carbon sequestration impacts on global climate change and food security. Science (Washington, DC) 304:1623-1627. doi:10.1126/science.1097396

Lal, R., D.C. Reicosky, and J.D. Hanson. 2007. Evolution of the plow over 10,000 years and the rationale for no-till farming. Soil Tillage Res. 93:1-12. doi:10.1016/j.still.2006.11.004

Littell, R.C., G.A. Milliken, W.W. Stroup, R.D. Wolfinger, and O. Schabenberger. 2006. SAS for mixed models. 2nd ed. SAS Inst., Cary, NC.

Loughin, T.M. 2006. Improved experimental design and analysis for long-term experiments. Crop Sci. 46:2492-2502. doi:10.2135/ cropsci2006.04.0271

Lyon, D.J., W.W. Stroup, and R.E. Brown. 1998. Crop production and soil water storage in long-term winter wheat-fallow tillage experiments. Soil Tillage Res. 49:19-27. doi:10.1016/ S0167-1987(98)00151-2

Martin, K.L., P.J. Hodgen, K.W. Freeman, R. Melchiori, D.B. Arnall, R.K. Teal et al. 2005. Plant-to-plant variability in corn production. Agron. J. 97:1603-1611. doi:10.2134/agronj2005.0129

NOAA-National Climatic Data Center. 2014. NNDC Climate Data Online. Natl. Climate Data Ctr., Washington, DC. http://www7. ncdc.noaa.gov/CDO/CDODivisionalSelect.jsp (accessed 15 Dec. 2014).

Norwood, C.A. 1999. Water use and yield of dryland rowcrops as affected by tillage. Agron. J. 91:108-115. doi:10.2134/agronj1999. $00021962009100010017 \mathrm{x}$

Norwood, C.A., and R.S. Currie. 1996. Tillage, planting date, and plant population effects on dryland corn. J. Prod. Agric. 9:119-122. doi:10.2134/jpa1996.0119

Pedersen, P., and J.G. Lauer. 2003. Corn and soybean response to rotation sequence, row spacing, and tillage system. Agron. J. 95:965971. doi:10.2134/agronj2003.0965

Peterson, G.A., D.J. Lyon, and C.R. Fenster. 2012. Valuing long-term field experiments: Quantifying the scientific contribution of a long-term tillage experiment. Soil Sci. Soc. Am. J. 76:757-765. doi:10.2136/sssaj2011.0413

Peterson, T.A., and G.E. Varvel. 1989a. Crop yield as affected by rotation and nitrogen rate. I. Soybean. Agron. J. 81:727-731. doi:10.2134/ agronj1989.00021962008100050005x

Peterson, T.A., and G.E. Varvel. 1989b. Crop yield as affected by rotation and nitrogen rate. III. Corn. Agron. J. 81:735-738. doi:10.2134/ agronj1989.00021962008100050007x

Pikul, J.L., Jr., L. Hammock, and W.E. Riedell. 2005. Corn yield, nitrogen use, and corn rootworm infestation of rotations in the northern Corn Belt. Agron. J. 97:854-863. doi:10.2134/agronj2004.0263

Porter, P.M., J.G. Lauer, D.R. Huggins, E.S. Oplinger, and R.K. Crookston. 1998. Assessing spatial and temporal variability of corn and soybean yields. J. Prod. Agric. 11:359-363. doi:10.2134/ jpa1998.0359

Porter, P.M., J.G. Lauer, W.E. Lueschen, J.H. Ford, T.R. Hoverstad, E.S. Oplinger, and R.K. Crookston. 1997. Environment affects the corn and soybean rotation effect. Agron. J. 89:441-448.

Rasmussen, P.E., K.W.T. Goulding, J.R. Brown, P.R. Grace, H.H. Janzen, and M. Körschens. 1998. Long-term agroecosystem experiments: Assessing agricultural sustainability and global change. Science (Washington, DC) 282:893-896. doi:10.1126/ science. 282.5390 .893

Rathke, G.-W., B.J. Wienhold, W.W. Wilhelm, and W. Diepenbrock. 2007. Tillage and rotation effect on corn-soybean energy balances in eastern Nebraska. Soil Tillage Res. 97:60-70. doi:10.1016/j. still.2007.08.008
Raun, W.R., H.J. Barreto, and R.L. Westerman. 1993. Use of stability analysis for long-term soil fertility experiments. Agron. J. 85:159167. doi:10.2134/agronj1993.00021962008500010029x

Ritchie, S.W., J.J. Hanway, H.E. Thompson, and G.O. Benson. 1997. How a soybean plant develops. Spec. Rep. 53. Iowa State Univ. Coop. Ext. Serv., Ames.

SAS Institute. 2014. The SAS system for Windows. Version 9.4. SAS Inst., Cary, NC.

Shapiro, C.A., R.B. Ferguson, G.W. Hergert, C.S. Wortmann, and D.T. Walters. 2008. Fertilizer suggestions for corn. EC117. Univ. of Nebraska, Lincoln.

Sims, A.L., J.S. Schepers, R.A. Olson, and J.F. Power. 1998. Irrigated corn yield and nitrogen accumulation response in a comparison of no-till and conventional till: Tillage and surface-residue variables. Agron. J. 90:630-637. doi:10.2134/agronj1998.00021962009000 $050011 \mathrm{x}$

Six, J., S.M. Ogle, F.J. Breidt, R.T. Conant, A.R. Mosier, and K. Paustian. 2004. The potential to mitigate global warming with no-tillage management is only realized when practiced in the long term. Glob. Change Biol. 10:155-160. doi:10.1111/j.1529-8817.2003.00730.x

Smith, R.G., F.D. Menalled, and G.P. Robertson. 2007. Temporal yield variability under conventional and alternative management systems. Agron. J. 99:1629-1634. doi:10.2134/agronj2007.0096

Stanford, G. 1973. Rationale for optimum nitrogen fertilization in corn production. J. Environ. Qual. 2:159-166. doi:10.2134/ jeq1973.00472425000200020001x

Swan, J.B., E.C. Schneider, J.F. Moncrief, W.H. Paulson, and A.E. Peterson. 1987. Estimating corn growth, yield, and grain moisture from air growing degree days and residue cover. Agron. J. 79:53-60. doi:10.2134/agronj1987.00021962007900010012x

USDA-National Agricultural Statistics Service. 2014. USDA/NASS QuickStats. USDA, Washington, DC. http://quickstats.nass. usda.gov/ (accessed 11 Dec. 2014).

Vanotti, M.B., and L.G. Bundy. 1994. Corn nitrogen recommendations based on yield response data. J. Prod. Agric. 7:249-256. doi:10.2134/jpa1994.0249

Varvel, G.E. 1994. Monoculture and rotation system effects on precipitation use efficiency of corn. Agron. J. 86:204-208. doi:10.2134/ agronj1994.00021962008600010036x

Varvel, G.E., and W.W. Wilhelm. 2003. Soybean nitrogen contribution to corn and sorghum in western Corn Belt rotations. Agron. J. 95:1220-1225. doi:10.2134/agronj2003.1220

Varvel, G.E., and W.W. Wilhelm. 2010. Long-term soil organic carbon as affected by tillage and cropping systems. Soil Sci. Soc. Am. J. 74:915-921. doi:10.2136/sssaj2009.0362

Verhulst, N., V. Nelissen, N. Jespers, H. Haven, K.D. Sayre, D. Raes et al. 2011. Soil water content, maize yield, and its stability as affected by tillage and crop residue management in rainfed semi-arid highlands. Plant Soil 344:73-85. doi:10.1007/s11104-011-0728-8

Vetsch, J.A., G.W. Randall, and J.A. Lamb. 2007. Corn and soybean production as affected by tillage systems. Agron. J. 99:952-959. doi:10.2134/agronj2006.0149

West, T.D., D.R. Grifith, G.C. Steinhardt, E.J. Kladivko, and S.D. Parsons. 1996. Effect of tillage and rotation on agronomic performance of corn and soybean: Twenty-year study on dark silty clay loam soil. J. Prod. Ag. 9:241-248.

Wilhelm, W.W., and C.S. Wortmann. 2004. Tillage and rotation interactions for corn and soybean grain yield ass affected by precipitation and air temperature. Agron. J. 96:425-432. doi:10.2134/ agronj2004.0425 